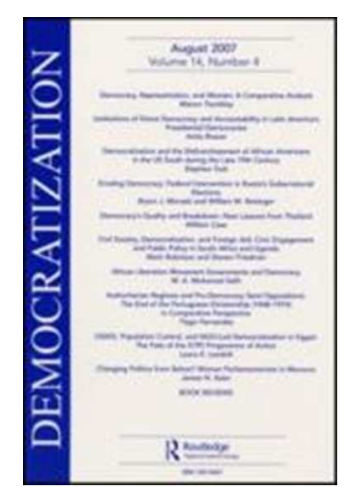

\title{
Social Media and Protest Mobilization: Evidence from the Tunisian Revolution
}

\begin{tabular}{|r|l|}
\hline Journal: & Democratization \\
\hline Manuscript ID: & FDEM-2013-0083.R1 \\
\hline Manuscript Type: & Original Article \\
\hline Keywords: & $\begin{array}{l}\text { Political Protest, Mobilization, Information Technologies, Social Media, } \\
\text { Tunisia }\end{array}$ \\
\hline \multicolumn{2}{|l}{} \\
\hline
\end{tabular}

SCHOLARONE $^{\text {Im }}$

Manuscripts 


\section{Social Media and Protest Mobilization: Evidence from the Tunisian Revolution}

\section{INTRODUCTION}

Over the past two decades, the political role of the Internet and digital social media has developed into a well-established topic of research on political communication and political participation. The Internet's prominent role in the diffusion of popular protest across the Arab World and the ouster of authoritarian regimes in Tunisia and Egypt has re-energized the debate on the implications of social media networks for political mobilization and patterns of protest diffusion, as well as the impact of social media networks on individual political engagement.

Much research on these aspects of social media has hitherto been conducted in the context of consolidated Western democracies on forms of political participation that tend to support the political system. Work has been carried out on how Internet use can be used as a direct influence on actions of legitimate governments through affecting the decisions of elected officials or indirect influence through the selection of officials. Typical activities include conventional political participation (voting, donating money, canvassing, attending political meetings and electoral rallies, being interested in politics) and lawful unconventional participation (signing petitions, participating in authorized demonstrations and strikes, political consumerism).

Political science literature argues there is a plausible positive relationship between an individual's exposure to and use of digital media and the degree of his or her political engagement (Brady, Verba, and Schlozman 1995). Social network platforms such as Twitter, 
YouTube, and Facebook have multiplied the possibilities for retrieval and dissemination of political information, and thus afford the Internet user a variety of supplemental and relatively low cost access points to political information and engagement. Social media users can be updated about their friends' political activities through their own News Feed. They can comment on these activities or join online discussion groups, which engage them in political conversation from the convenience of their homes at any time of the day. They can "befriend" political organizations online and stay informed about their activities without having to attend a meeting or a rally. In this way, the more social and interactive culture of online communication that developed with the emergence of the Web2.0 holds potential for the democratisation of political engagement.

Digital media use has considerably lowered the transaction costs associated with political action; however, despite these positive attributes, its impact on individual participation rates has remained "underwhelming" (Bimber and Copeland 2011). A meta-analysis of 38 studies on the impact of Internet use on civic engagement between 1995 and 2005 confirms a positive but very modest impact (Boulianne 2009), which appears to be moderated by factors long established as standard predictors of political participation, such as social capital (Gibson, Howard, and Ward 2000) and political interest (Xenos and Moy 2007). At the mesolevel of social organization there is broad scholarly consensus that the Internet has expanded the 'collective action repertoire' of organizational actors, such as social movements and grassroots organizations (Geser 2001; Doug McAdam, Sidney Tarrow, and Charles Tilly 2001; van Laer and van Aelst 2009). The strategic toolkit of these actors has been complemented by the informal procedures that the Internet offers for mobilization. The structure of digital networks facilitates decentralized forms of campaigning based on parallel activities of independent individuals. The task of information diffusion can be 
delegated to a multitude of members who act as unpaid volunteers by circulating received messages throughout their personal networks. There are significant multiplier effects as users share information across their networks, expanding the reach and impact of information. The Internet has thus arguably become an important resource for political mobilization, which reduces the costs previously allocated to professional communication (Geser 2001; Krueger 2006).

At the same time, the political implications of the Internet in the context of non-democratic systems remain relatively under researched, even though there is a widespread popular belief that the Internet can undermine authoritarian rule. Case study research from the Berkman Centre for Internet and Society investigates the impact of information and communication technologies (ICTs) on civic engagement in authoritarian regimes (Chowdhury 2008; Goldstein 2007; Goldstein and Rotich 2008), as have several additional publications on the cases of Iran (Kelly and Etling 2008; Rahimi 2003; Tezcür 2012; Weitz 2010) and China (Chen 2009). By means of a qualitative case study that analyses a convenience sample of news reports and social media messages produced over the course of the Egyptian uprisings (ELTANTAWY and Wiest 2011) come to the conclusion that social media introduced a novel resource that provided swiftness in disseminating information; and helped to build and strengthen ties among Egyptian activists.

By and large, however, the democratic transitions literature, however, is still a long way from having established a clear understanding of the relationship between new media and political participation and protest mobilization under authoritarian rule and the rich empirical data - particularly micro data - needed to establish such causal influences have yet to be gathered (Aday et al. 2010; Kalathil and Boas 2001; Lynch 1999). 
The Tunisian uprising of 2010-2011 provides an excellent opportunity to address this research lacuna. Based on background talks with 16 Tunisian digital activists and a survey among 437 Tunisian Internet users conducted in early 2012, this article analyses the use of the Internet as a significant resource for protest mobilization in the case of Tunisia. Previous analyses of the Tunisian case show that early 'tactical concessions' (Gränzer 1999; Risse, Ropp, and Sikkink 1999) from the regime to a growing protest movement in the 1980s halted political reform and led to a deterioration in the human rights situation, making Tunisia a 'least likely' case where protest would be possible to make a contribution to political transformation (Eckstein 1975; Landman 2008 ). Hence, there are good reasons to argue that political reform in Tunisia seemed unlikely; however, this article shows that the Internet significantly contributed to the wave of protest that brought down the Ben Ali regime. Drawing on insights from 'resource mobilization theory' (RMT), we show that social media (1) allowed for a 'digital elite' to break the national media blackout in Tunisia through brokering information for mainstream media; (2) provided an element of 'emotional mobilization' through depicting atrocities associated with the regime's handling of the protests which, in turn, led to the formation of a national collective identity supportive of protest; (3) enabled intergroup collaboration that facilitated a large 'cycle of protest' to develop.

In order to sustain this argument, the paper is divided into four sections. The first section outlines trends in social movement theory to show how Internet use and social media 'fit' in terms of explaining the contribution of new technologies to the kind of mobilization that took place in Tunisia in 2010 to 2011 . The second section examines how a digital elite in Tunisia used new technologies to create networks and frame the mobilization against the regime, aggregate discontent across different opposition groups and overcome regime 
attempts to control the flow of information. The third section presents statistics drawn from the survey data to show how increased Internet use raised probabilities for Tunisians to become involved in anti-government protest. The final section draws tentative conclusions about the Internet and social media as a resource for protest mobilization more generally.

\section{RESOURCE MOBILIZATION AND NEW TECHNOLOGIES}

It has been argued that public protest under authoritarianism is rare (Tullock 2005), spontaneous, politically and geographically isolated, and will largely occur without coordination through organized social movements (Doug McAdam, Sidney Tarrow, and Charles Tilly 2001; Tilly 2004)) In explaining the breakdown of authoritarian regimes, the political economy literature has consequently focused on the role of elites. It is argued that the most serious challengers of autocrats come from their own ruling coalitions, i.e. the military or security forces (Geddes 2003, 2006), the ruling party or coalition (Boix and Svolik 2008; Guriev and Sonin 2009; Magaloni 2008), or their royal families (Fjelde 2010; Kricheli, Livne, and Magaloni 2011)). Where attention is given to citizen groups, it is in relation how their support affects the interaction 'game' between elites from the government and opposition (Colomer 2011; Colomer and Pascual 1994; Przeworski 1991). Beyond the gametheoretic literature, however, work on social movements has shown the possibility for popular mobilization under authoritarianism contribute to regime liberalization and democratic transformation e.g. (Foweraker 1989, 1995; Foweraker and Craig 1990; Foweraker and Landman 1997; Hawkins 2002; Landman 2008 ; Risse, Ropp, and Sikkink 1999).

Not only does civilian-led anti-government protest occur under authoritarianism, but it can even spread across state boundaries through different processes of diffusion. Indeed, the 
past three decades saw four cross-national waves of anti-regime mobilizations different regions of the world: (1) popular opposition and regime change in Latin America in the 1970s and 1980s; (2) the spread of popular challenges to communist party rule in the Soviet Union and Eastern Europe from 1989 to 1991; (3) the 'colour' revolutions of post-communist Europe and Eurasia from 1996 to 2005; and (4) the protests in the Middle East and North Africa (MENA). Other cases of popular but less successful anti-authoritarian protest include the Tiananmen Square Protests in China in 1989, the Student Revolt in Indonesia in 1998, the Saffron Revolution in Myanmar in 2007, and the Green Movement in Iran in 2009 and 2010.

Studies that examine why social movement arise in the first place focus their attention on sources of collective grievance and common identities that lead to popular mobilization and protest (see, e.g. Acemoglu and Robinson 2005; Hendrix, Haggard et al. 2009). Studies that examine how social movements attract participants and members to take part in their activities focus on the role of social movement organisations (SMOs) and the mobilization of important resources that are necessary for sustained collective actions, such as money, communications, membership, and the provision of 'selective incentives' to overcome the problem of collective action (see e.g. Lichbach 1998; Putnam and Fieldstein 2003). Studies that focus on the impact of social movements focus on their goals, their legal and institutional impact (including regime change), and the degree to which values and political behaviour have been altered by prolonged periods of social movement activity.

This article explains how social movements can attract participants for collective action against an authoritarian regime that has been challenged unsuccessfully in the past. We show that in Tunisia, there was a latent desire to form collective movements under conditions of grievance. Particularly, we focus the role of new technologies as a significant resource for protest mobilization. We demonstrate that the Internet provided the means for 60 
aggregating grievance, building networks across disparate communities within Tunisia and communicating strategies for successful opposition to the Ben Ali regime.

While it would be incorrect to say there is no public sphere under authoritarianism (Foweraker and Landman 1997) the ability for civil society to mobilize collective action around grievances is made more difficult by the fact that the national narrative is often controlled by the government which typically resorts to a mix of censorship and intimidation to suppress negative information about its performance. By providing a space for increased free speech, the Internet poses an existential threat to the ability of authoritarian governments to control the national narrative (Kuebler 2011). Ordinary citizens, not necessarily linked to any political movement, may share their grievances by voicing them through online social networks, and once such information is leaked to the public it may unleash effects at two different levels. At the micro level, it can act as a cognitive catalyst that pushes people into protest action. At the macro level, media content that evokes negative emotions has a high potential to "go viral", where anger and anxiety as emotional states of heightened physiological arousal are key in driving social transmission and diffusion (Berger and Milkman 2010).

The limited supply of information under authoritarian conditions means that individuals can expect to pay high personal costs (arrest, incarceration, or death on streets) if they participate in unsuccessful protest activity that results from the lack of coordination and sharing of information. The key challenge for the formation of protest under authoritarian regimes is that potential protesters will only turn out to protest if they are convinced that a large number of others will do the same (Hendrix, Haggard, and Magaloni 2009). Social networks provide individuals with information that allows for a better calculation of their 'individual risk threshold' (Granovetter 1978) in two important ways. First, online content 
that documents past protest events may trigger informational cascades that lead to mass civil uprisings. Second, event management features (e.g. "Facebook events") offered by social networking sites inform users about the prospective participation in upcoming events.

The potential of new technologies to enhance the ability of ordinary people to share information of consequence should be understood in terms of Resource Mobilization Theory (RMT). RMT claims that open and affluent societies provide more favourable conditions for contentious groups to thrive, thus making protest more common (Dalton and van Sickle 2005). Here, the existence of extensive non-governmental organizations and other civil society groups provide the crucial variable linking dissatisfaction to political action, as they allow citizens to engage in a variety of voluntary associations freely and to develop the necessary social and organizational skills to promote their interests (Putnam 2000; Putnam and Feldstein 2003). Such groups are able to raise funds, increase membership, and engage in communication and awareness-raising strategies to bring about their goals. During times of political stress, such groups of disparate social movement organizations can come together in larger 'cycles of protest' to challenge the regime on significant policy issues (Doug McAdam, Sidney Tarrow, and C. Tilly 2001; Tarrow 1994). In accounts of social movements in more open societies, studies that adopt the RMT framework focus on how elites in the opposition work through networks and social movement organisations (SMOs) to harness a collection of resources that help aggregate grievances and take advantage of the changing political opportunity structures that can emerge during a cycle of protest (e.g. a shift in elite alignments, critical elections, exogenous economic shocks, etc.). 
While the occurrence of protest in closed authoritarian societies may appear to run counter to the basic premises of RMT, many authoritarian societies have the presence of latent networks, proto-organisations and community leaders (or at least those that have not been arrested, exiled or 'disappeared'), all of which can provide the basis for social mobilisation. The advent of the Internet builds on ever denser communication infrastructures as societies develop and provides a resource for movement leaders that can be used to orchestrate protest where institutional distrust looms large and civic activism is systematically suppressed. Internet use can coincide with participatory dynamics characterized less by formal organizational relationships and more by loosely-knit personal networks increasingly mediated through electronic communication (Wellman et al. 2003). The availability of Internet communication technologies can enable activist groups to communicate with potential constituencies across large distances, including diaspora communities living outside the country in question. Thus, they constitute important resources to achieve intergroup-collaboration and challenge the strategies of social isolation typically employed by authoritarian regimes to obstruct civil society groups from forming and operating..

In addition to the idea of the Internet as a resource, the emergence of new technologies can also be seen as way in which potential protesters are targeted by 'recruitment agents' who inform them of upcoming protest events and encourage their participation (see Snow, Zurcher, et al. 1980). The most infuriated and risk-acceptant citizen will not be able to participate in an anti-government demonstration if he or she does not know a demonstration event is actually taking place. The likelihood of a person to become mobilized increases with their network 'embeddedness' and movement leaders can use such embeddness to help recruit larger numbers of participants. Overlapping memberships allow 
information about upcoming protest events to travel beyond the boundaries of a network of hard-core activists and 'spill over' to networks of less-engaged citizens (Carroll and Ratner 1996). Another important function of social networks in this context is to build a collective identity supportive of protest action, which is achieved through interpersonal conversations with other network members. Collective identities motivate protest participation by providing the potential participant with a sense of in-group solidarity and an oppositional consciousness of "us" versus "them" (Friedman and McAdam 1992; van Laer 2011).

It can thus be assumed that the Internet is conducive to increased awareness about collective action events, such as mass demonstrations of the kind observed during the Arab Spring. The more embedded an individual Internet user is in terms of memberships in different online social networks, the higher should be the likelihood of him or her being targeted by an online mobilization attempt, which as we shall see, was increasingly coordinated by a digital elite that could collate, translate, and communicate disparate nodes of grievance in the country in ways that galvanised a more national focussed critique of the Ben Ali regime.

Taken together, this article is concerned with how interaction between aggrieved individuals was enhanced through new technologies, and how new technologies contributed to the wave of protest mobilization in Tunisia. We argue that aggrieved individuals under authoritarian regimes face additional challenges that for successful mobilization, and that the Internet and social media provide a resource to meet some of these challenges. In a country like Tunisia with an authoritarian regime, disparate communities with varied dialects, and a lack of shared information, the Internet provided access to information, 
lowered transaction costs, buttressed networks of activists and contributed to antigovernment mobilization particularly after the self-immolation of Mohamed Bouazizi on 17 December 2011.

In order to examine the contribution of new technologies to protest mobilization in Tunisia, we use three main empirical sources: (1) the relevant secondary literature, (2) a series of background talks conducted with 16 cyber activists and citizen journalists during a field trip to Tunis in October 2011, and (3) data from an online survey among Tunisian Facebook users conducted between 1 March and 31 May 2012. For the background talks, the activists were asked to provide information about their own online and offline protest activities prior to and during the uprising, to describe the nature of digital activist networks in Tunisia and their own position in these structures, to provide a personal assessment of the contribution of ICT to the protest movement, and to help identify online contents which they regarded as having been particularly influential. ${ }^{1}$ For the survey data we used the online software SurveyMonkey, where the survey contained a total of 34 questions and took about 12 minutes to complete. It was conducted in Arabic and was pilot-tested for comprehensiveness and ease of use among native Tunisian-Arabic speakers prior to its launch.

\footnotetext{
${ }^{1}$. Interview partners included independent bloggers, bloggers for digital formats of traditional media outlets, and activists belonging to diverse networks such as the collective Blog Nawaat, the self-described "cyber think tank" Takriz - which maintains close ties to the Anonymous cyber movement and radical ultra groups of Tunisia's football fan-scene, as well as members of the Tunisian Pirate Party, which at that time had not yet been officially recognized as political party. Political activism in times of regime transformation comes with uncertainties for those who engage in it. This is especially true where activists have been socialized in the political culture of a recently toppled authoritarian regime with the outcome of the transition process remaining unclear. Such was the situation during the field trip for this study, which was undertaken in the week leading up to Tunisia's first democratic election following the ouster of President Ben Ali. Taking into account the diverging risk perceptions of interview partners, the information given by them was therefore subsumed into the narrative of the case study, unless they explicitly agreed to their identity being revealed.
} 
Participation in the survey was promoted using a respondent-driven sampling technique. ${ }^{2}$ To build the sample, we formed an online group on Facebook dedicated to the discussion of the role of the social media in the Arab Spring and invited those cyber activists to join the group to which contacts had been established during the field. The group was then systematically enlarged using the Facebook friendship suggestion algorithm whereby the network recommends new friends to its users on the basis of their existing friends. Once the survey had been launched, an invitation to participate was sent to members of this group using the Facebook group event organizing function. The invitation message contained the survey's URL, a description of its academic purpose, and suggested to circulate the survey URL among friends, relatives and colleagues. No monetary or material incentive was offered to the respondents. The survey resulted in 437 responses; a non-random sample which provides valuable insights into a subset of Tunisian citizens previously shown to have been well educated, digitally literate, and socially interconnected (see Annex 1).

\footnotetext{
${ }^{2}$ The method applied here is similar to the chain-referral sampling methods which have hitherto primarily been used to contact hidden or difficult-to-reach populations such as drug users or sex workers (Salganik and Heckathorn 2004) While the "pass-along effect" (Norman and Russell 2006) involved with this technique is helpful in increasing sample size and reducing the transaction cost of response collection, it is often criticized because respondents are not randomly selected from a known sample frame and this limitation risks biasing the sample and diminishing the generalizability of inferential statistical tests. While acknowledging that these threats are real, as the online population has grown and the Internet has become more embedded in everyday life, it has become increasingly common for social scientific inquiries to proceed with samples derived through this process (Kaye and Johnson 1999).
} 


\section{DIGITAL ELITE AND THE AGGREGATION OF DISCONTENT}

During the 1990s, governments in the Muslim world adopted strategies to regulate the use of ICTs that varied across regime type. In liberal regimes competition in the ICT-market was permitted, while in more autocratic regimes ICT development was controlled by state owned companies, which reported directly to the government and monitored online content (Howard 2011). Tunisia was somewhere in the middle of this spectrum. Starting from the middle of the 1990s, President Ben Ali's administration invested heavily in the telecom sector. Within a decade, Tunisia had one of the most developed telecommunications infrastructures in Northern Africa. Competition between eleven Internet service providers led to one of the most developed Internet markets in the region (Reporters Without Borders 2004). By 2008 there were 1.7 million internet users out of a total population of 10.2 million, who could access the Internet from their homes and / or work, as well as from public Internet centres (publinets) set up throughout the country. Ben Ali's strategy to depict himself as a role model for the promotion of ICTS in the developing world sold well internationally when in 2001, Tunisia was chosen to host the second stage of the UN-World Summit on the Information Society in 2005.

\section{Government censorship activities}

Despite its positive international image, the Ben Ali regime went at great lengths to control and censor communication on the Web. Under the pretext of preventing access to material contrary to public order and morality, the Tunisian Internet Agency (ATI), was legally authorized to intercept email messages. Since the ATI was the gateway from which all of Tunisia's Internet Service Providers (ISPs) leased their bandwidth the agency was also able to monitoring software onto their servers (OpenNet Inititative 2009). While the ATI tried to 
conceal its censorship activities, the somewhat clumsy practice of generating fake 404 "File not found" error messages for blocked websites soon gained the agency the nickname "Ammar 404"1. In addition, the ATI exercised control by obliging private Internet café owners and the publinets to register the ID numbers of Internet users and by holding them legally responsible for their customers' online activities.

Online censorship was stepped up considerably in 2008 in response to strikes and demonstrations against corruption of the Phosphate Mining Company (Compagnie Phosphate de Gafsal) in the region of Gafsa. While state-controlled media ignored the events, Internet activists began to cover them on Facebook. In August 2008 Facebook was blocked at the request of Ben Ali who cited national security violations by terrorists (Chomiak 2011; International Crisis Group 2011), but after considerable online protest the government lifted the blockade a few weeks later and switched to a strategy of covert surveillance of the social network. According to The U.S. State Department and the Committee to Protect Journalists (CPJ), the government ordered Tunisian ISPs to intercept the log-in details of Tunisian Facebook users and relay them to the ATI which then used them to either block the accounts entirely or remove undesired content (Lister 2011).

\section{Cyber-activism $1998-2010$}

Cyber activism in Tunisia is a phenomenon that long predates the Arab Spring. As early as 1998, two anonymous activists named "Foetus" and "Waterman" founded the group Takriz², described as a "cyber think and street resistance network". From its beginnings, the group clearly targeted the country's politically alienated youth as its core audience through a combination of aggressive street slang and irreverent mockery of the authorities, which soon 
caught the regime's attention. Takriz's website was blocked within Tunisia in August 2000, but soon other sites sprang up to take its place. The collective blog Nawaat ${ }^{3}$, co-founded in 2004 by the exiled activists Riadh Guerfali and Sami Ben Gharbia, sought to provide a public platform for Tunisian dissident voices and publish information about the regime's corruption and human rights violations.

Other digital activists started out with cultural or entertainment topics and became politicized along the way in reaction to the regime's increasing repressiveness. Lina Ben Mhenni, a lecturer in linguistics at the University of Tunis, started out reporting on the capital's club scene on her blog Nightclubbeuse, but from 2009 increasingly reported on social and political issues which led the authorities to block her site in early 2010. The relaunched version of her blog A Tunisian Girl adopted a decidedly political tone that won her several journalism awards as well as a Nobel Peace Prize nomination in 2011 for the courageous documentation of the regime's human rights violations.

These examples show that a political culture of dissent existed prior to the events of December 2010. The Internet provided an alternative public sphere that was at least partially shielded from the government's unilateral oversight and control. Tunisians were able to form solidarities through shared feelings of repression and humiliation and to formulate a collective alternative discourse (Chomiak 2011; International Crisis Group 2011). Tunisia's cyber avant-garde, however, was dominated by affluent, well educated, and polyglot individuals with a high degree of cultural capital (Lim 2013) - a social profile characteristic for early ICT adopters throughout the developing world (Norris 2001). Yet it would be inaccurate to dismiss their network as a socially exclusive club. The early opening of the telecom market to free competition had considerably reduced the cost of Internet access, such that Internet use was not the privilege only of the economic elite (Howard 
2011). However, the ability for bloggers to convey their political messages to a critical mass of citizens was thwarted by tight control from the Ben Ali regime. According to Kuebler (2011), this limited impact of blogging between the late 1990s and 2010 can be attributed to its failure to build "the bridge from an elitist medium to the general public sphere". As illustrated in Table 3, prior to the Revolution traffic on the websites of Tunisian blogger communities such as Nawaat originated mainly from the host countries of sizeable Tunisian diaspora communities.

\section{[Table 1 about here]}

Digital activists had thus stepped-up their efforts to connect with both international and domestic constituencies. Several core activists started to become active in international blogger communities, such as Global Voices, ${ }^{4}$ to increase their visibility abroad. Some received training in e-journalism from programs funded through the US Middle East Partnership Initiative (MEPI), which focused on training journalists throughout North Africa and the Middle East in the years leading up to $2010 .^{5}$

\section{Protest 'Ignited': 17 December - late December 2010}

The event that finally undid the ability of Ben Ali's security apparatus to control the public sphere occurred in the marginalized provincial town of Sidi Bouzid southwest of Tunis. On 17 December 2011, distress triggered by socioeconomic, generational and geographic disparities within Tunisia's many governates was epitomized by the self-immolation of Mohammed Bouazizi. The 26 year-old fruit seller set himself on fire after a female police officer had confiscated his wares because he did not have a vendor's permit and publicly humiliated him by slapping him in the face. By committing his desperate act in front of the office of the regional governor, Bouazizi forced the regime to assume political and moral 
responsibility for his situation, thus turning him into the symbolic representative of millions of young Tunisians who lacked the opportunity for socio-economic advancement (Aday et al. 2010; Lynch 2012). The same day, members of Bouazizi's family, accompanied by trade unionists, marched to the police headquarters to express their anger. The protests soon turned into violent clashes between the police forces and members of Bouazizi's extended family, neighbors and youth who identified with his plight. Within a week, the protests spilled over to several neighboring cities. However, unlike in Gafsa two years earlier, the regime failed to contain the uprising and limit its ability to spread beyond the region. By the time Bouazizi died in hospital from his injuries on 4 January, what had begun as a local, socio-economically, motivated protest had turned into a nationwide anti-regime movement with tens of thousands of Tunisians from all levels of society demanding Ben Ali's fall. Bouazizi's death provided the necessary collective frame of reference to propel the online anti-regime movement onto the Tunisian street. But how did this information manage to break the filter of state-controlled media to reach such a broad audience so quickly?

One answer lies in the way that the online networks that had developed previously interacted with traditional international media outlets. Previous analyses of the Internet's role in the context of the Egyptian revolution (e.g. Aouragh and Alexander 2011) warn against interpretations that isolate the Internet form other with which they formed powerful synergies. The same holds true for the case of Tunisia: The initial protests in Sidi Bouzid were recorded by participants with cell phone video cameras and posted on personal Facebook profiles. On the eve of the revolution, Facebook penetration still hovered around a modest $17 \%$ (Dubai School of Government 2011). It is unlikely that this information would have reached a mass audience had it not been for a small elite of digital activists, many of them 
operating from exile, who acted as information brokers. Around the globe, these activists now joined efforts to screen Facebook for protest related posts, translating the material, ${ }^{6}$ and structuring it into a coherent narrative, as Yassine Ayari explains:

When the revolution came I was in Belgium. At that time I was already known through my blog. I had 2000 or 3000 friends on Facebook which gave me a little bit of influence. So I took a vacation from my job and sat with three other friends, PCs, pizzas, and a telephone. We tried to use all the information we could handle: status updates, pictures, videos. When we heard that something happened in Kasserine or somewhere else, we'd pick up the phone, we'd know someone who knows someone and we would find the information and post it (Yassine Ayari) ${ }^{7}$

Networks like Global Voices and Nawaat started to run special online features covering the protests and spread the word through their own social media channels on Facebook, Twitter, and YouTube. Once the information had been made available in a publishable form, international broadcasters were able to pick it up and re-import it into the country, thus 'leapfrogging' the blackout imposed by Tunisian state-media gatekeepers. Social media footage about the Sidi Bouzid protests first appeared on Al Jazeera on 20th December $2010 .^{8}$ It was only through this complex threefold interaction between non-elite protesters, strategically oriented digital activists, and international broadcasters that the information about the death of Bouazizi and the ensuing protests were able to reach a larger portion of the Tunisian society. 
Protest escalation and regime collapse: late December 2010 - 14 January 2011

Over the second week of the conflict, the movement expanded both socially and politically. Unemployed youth, who had so far been the socially dominant group among the protesters, were joined by employed professional and occupational group. The National Bar Association and the regional branches of the UGTT (Union Générale Tunisienne du Travail) emerged as poles of contestation, giving the movement both structure and sustainability (International Crisis Group 2011; Lynch 2012; Saidani 2012 ). Politically, the movement radicalized with socio-economic demands rapidly transforming into overt challenges to the regime, most clearly expressed by the slogan Ben Ali dégage! $!^{9}$

The regime responded with increased repression on the one hand, and an almost complete breakdown in public communication on the other hand. Between the 8th and 10th of January, police violence resulted in the deaths of 50 protesters according to union and hospital sources (International Crisis Group 2011). Ben Ali had only addressed the nation in a first televised speech on $28^{\text {th }}$ December, promising to respond to the protesters' demands. Thereafter, almost two weeks elapsed before in a second speech on $10^{\text {th }}$ January he promised to create 300.000 jobs over the next two years, but at the same time condemned the protests as "terrorist acts" orchestrated by foreign interests. These delayed and disconnected reactions from the regime stood in harsh contrast to a reality that had become visible for all to see through social media, and significantly contributed to transforming a spontaneous and locally-rooted movement into a determined national revolution.

Towards the end of December 2010, web activists from the capital had begun to travel to the remote regions of the country to cover the events and transmit them through Facebook 
real- time videos. Although Al-Jazeera had only one correspondent based in country and its Tunis office had been shut down (Lynch 2012), the TV channel could now draw on a wealth of footage circulating on the web which it broadcasted into Tunisian households without an Internet connection. One video with particular impact was recorded by a medical student at the emergency ward of the Kasserine municipal hospital ${ }^{10}$

You could see people had been killed, their heads blown up [...] Videos like this are shocking, but that's what good about them. Because many Tunisians did not have a problem with Ben Ali. They said: "we're ok, we are not poor we have food, we have hotels, we have beaches... it's ok. Where is the problem!?" But when you show them stuff like this they radically change their point of view about the system (Haythem El Mekki). ${ }^{11}$

During the final days of the uprising, an important function of the Internet consisted in helping to overcome the collective action problem associated with protest under authoritarian regimes. Reports about large scale demonstrations helped many Tunisians to overcome the barrier of fear that had so far prevented them from taking offline action. On $12^{\text {th }}$ January the UGTT called for a rally in Sfax. With about 30,000 people in the streets, the city witnessed the largest demonstration prior to the fall of Ben Ali and is considered the revolution's point of no return:

Everyone who saw the video about the demonstration in Sfax said: if this has happened in Sfax then it can happen in Tunis. And if it happens in Tunis then it will be a success (Sara Ben Hamadi) ${ }^{12}$. 
On 13 January, Ben Ali delivered his last televised speech, in which he announced that he would abstain from running as a presidential candidate in 2014 and offered to call for early parliamentary elections. It was too little too late. According to Schraeder and Redissi (2011), especially students and young people under 30 felt reluctant to grant the regime another four years to craft an authoritarian transition. Many of them saw the mass demonstrations staged for $14^{\text {th }}$ January in the centre of Tunis as a unique opportunity of their generation to break with a tradition of quiescent obedience and considered participation in these protests as a patriotic duty. It also appears that social media were a crucial element in the politicization and mobilization of the young urban middle class and elites. As Nadia Zouari, a Tunis based plastic artist and feuilletonist for Le Temps, remembers the final days leading up to the regime's fall ${ }^{13}$ :

During this period we spent white nights in front of the computer. Facebook connected us to the things that were going on and it felt like we were living in a different country. Because in Tunis you could lead a normal life. But in Sidi Bouzid, Kasserine and Kef it was totally different. And when we saw what was happening to people there we decided that we had to show solidarity with them.

Religious political actors seem to share this interpretation of the Internet's role in mobilizing urban middle classes. In an interview by the International Crisis Group (2011) a member of the moderate Islamist Ennahda party states: "The internet caused the failure, to all of our surprise, of the regime's project of creating a consumerist and apolitical middle class". It appears then, that another important role of Facebook and other social media was to span a 
bridge between hitherto unrelated socio-economic groups, thus providing the basis for intergroup collaboration that facilitated a large cycle of protest to develop. On 14th January, confronted with the largest anti-government demonstration that Tunis had ever seen, Ben Ali and his family fled the country on a plane to Dubai.

\section{THE INTERNET AND MOBILISATION: SURVEY EVIDENCE}

These developments in the provision, restriction and use of the ICTs in Tunisia, as well as the strong anecdotal evidence from our interviews suggest that the internet and social media contributed to the downfall of the Ben Ali Regime. In this final empirical section, we analyse the results of our online survey to show that indeed respondents who were more active internet users were significantly more likely to engage in anti-government protest activity.

Our analysis proceeds by looking at the frequency of responses across questions in the survey that capture internet uses, attitudes towards the Ben Ali regime and the likelihood to become involved in anti-government protest activity. We then show how we constructed a scale of internet use and a scale of likelihood to engage in political protest activity. With these two scales, we engage in a simple bivariate analysis and then move on to an orderedprobit multiple regression analysis to examine the importance of Internet use for protest mobilization in the presence of additional explanatory variables.

Table 2 provides the descriptive statistics for the variables of interest. The survey reveals a complex mix of attitudes to the Ben Ali regime itself and offers different measures of attitudes that variously map onto the main theoretical concepts outlined above. There are several questions on government capacity to run the country, where two dimensions of attitudes relating to managing the economy and protecting rights and freedoms emerged. 
For managing the economy, we collapsed four questions on the economy, jobs, income distribution and corruption into a scale, where the frequency of the respondents in our sample with strong opposition to the regime is high (i.e. they strongly disagreed across all four questions relating to government capacity in that issue area). For rights and freedoms, we collapsed three questions relating to freedom of speech, freedom of the press and general respect for people's rights under the Ben Ali, where the frequency of opposition again is very high. We see high response rates and good variation across all the components of the two composite scores. Figure 1 shows both scales of opposition among the respondents, where higher scores on the scale show greater levels of discontent.

\section{Figure 1 about here}

In addition to these general levels of opposition to the regime, $59.5 \%$ of the sample expressed anger, sadness and frustration over online pictures and videos that documented the regime's heavy handed response to opposition activities and made them doubt the legitimacy of the regime itself. These attitudes were joined with a general level of national pride in opposing the regime, where $93.5 \%$ agreed strongly or agreed that as Tunisians they needed to support the protest movement and $96.1 \%$ agreed strongly or agreed that the events filled them with a sense of pride about being Tunisian ${ }^{3}$. These findings emphasize the Internet's role as a transmitter of emotions that contribute to the formation of collective

\footnotetext{
${ }^{3}$ In an open ended survey on social media use conducted among 50 Tunisians Esseghaier (2013) observed similar motifs with respondents reporting a sense of unity, solidarity, pride, and connection. The respondents discussed a sense of unity, solidarity, pride, and connection, fostered through the physical demonstrations. - See more at: http://wi.mobilities.ca/tweeting-out-a-tyrantsocial-media-and-the-tunisian-revolution/\#sthash.nXQaMhxS.dpuf
} 
identities supportive of protest action - a function that has long been regarded as essential by attitudinal and network approaches to political activism (Friedman and McAdam 1992; Jasper and Poulsen 1995, van Laer 2011).

In terms of intergroup collaboration it is interesting that $73 \%$ of respondents reported that in order to keep informed about what was happening, they started to connect with people on social networks that they had not previously known. $73.8 \%$ of respondents had learned through the Internet that a large number of people had signed up for a demonstration in their own town, city or municipality. Combined, these two findings indicate that social media may indeed have facilitated a spillover effect whereby protest information filters from the networks of political activists into those of less-engaged citizens (Carroll and Ratner 1996).

In rationalist terms it is interesting that $80.4 \%$ of the sample 'agreed strongly' or 'agreed' to the statement that based on what they saw on the Internet they came to believe that the protest movement would achieve its goal of bringing down the Ben Ali government. $82.2 \%$ agreed strongly or agreed that from what they were able to see on the Internet, the number of people involved in the protests outnumbered those who supported the regime. At the same time the majority of respondents were conscious of the risks involved with protest action: $81.9 \%$ felt that their participation in protests could result in injury, arrest or other forms of repression. While this could have resulted in a lack of incentive to personally participate in protest action, the results also indicate that the free rider effect may have been outweighed by feelings of personal efficacy and in-group solidarity as $53.6 \%$ felt that they could make a positive and $92 \%$ agreed strongly or agreed that they had a lot in common with those involved in the protests. 
Network embededness among respondents was high with $65.1 \%$ of the sample indicating to have more 200 friends in their primary online social network. Membership in popular social network sites varied across Facebook (98.4\%), YouTube (46.4\%), Twitter (42.7\%), Linkedln (23.0\%), Dailymotion (13.7\%), Flickr (7.4\%) and Vimeo (7.1\%). ${ }^{14}$ But did the use of the internet and participation in social media contribute to mobilization for protest?

To address this fundamental question, we combined several related questions into two scales. First, we combined seven questions on the frequency of use of the Internet for protest-related activities, which include questions relating to online discussion of the political situation with known and unknown people, online searches for information on local and national protest events, and the use of the Internet to share information within Tunisia as well as to international audiences ${ }^{15}$. Second we combined four questions on offline political behavior during the revolution, including such activities as participating in demonstrations; leafleting, wearing clothing, buttons or stickers with political messages; or discussing politics face to face. Figure 2 shows both scales, where it is clear that there is a cumulative frequency for respondents who used the internet for protest-related activity, while their cumulative frequency of political activity tends toward the lower end of the scale. Despite the difference in engagement between on-line and off-line activities, our analysis shows that there is a significant relationship between internet activity and the participation in protest activity.

\section{Figure 2 about here}

As a first look at the relationship between internet use and protest activity, we present a cross-tabulation based on dichotomizing both scales and comparing frequency counts for low and high internet use against low and high protest activity. The cross-tabulation (Figure 
3) shows that respondents with low internet use were less engaged in protest activity than those respondents with high internet use (compare the shaded areas), where the difference in percentages is statistically significant $(\chi 2=17.767 ; p<.001)$. Such bivariate results, however, need to take into account additional explanatory variables to check the degree to which internet use is indeed related to protest activity.

\section{Figure 3 about here}

To this end, we tested a series of increasingly complex models using ordered-probit multiple regression, which is the best statistical estimator given the ordinal scale that we created for political protest activity. ${ }^{16}$ Our dependent variable is the scale for level of protest activity and our independent variables variously include the level of internet use, a scale for opposition to the Ben Ali regime to be read as an indicator of socio-economic and political grievance, a scale for political efficacy, a scale for support for liberal religious views, level of education, occupational status, age and gender. The results for six models are shown in Table 2.

\section{Table 2 about here}

Reading across the different models, the results show that protest-related Internet use is positively and significantly related to increased offline protest activity among the respondents, even after controlling for an increasing number of additional independent variables. There are other findings of note alongside the main finding for Internet use. First, across models 2 to 6 , opposition to the Ben Ali regime also contributes to the probability of becoming involved in protest activity - a finding that goes in line with previous research on 
the effect of attitudinal and opinion issues on protest behavior (Lowrance 2006; Pierce and Converse 1990). Second, across models 3 to 6 a weak sense of political efficacy lowers the probability of engaging in political protest activity. This finding fits in with the recent revival of personality as an explanatory variable for political behavior in social science research (Gerber et al. 2010; Mondak 2010). John et. al. (2011) for instance demonstrate that people with an internal locus of control are significantly more likely to start a mobilization. Third, across models 4 to 6 support for more conservative religious views lowers the probability of involvement in protest activity. This is interesting since it supports the notion that despite the success of the Islamist Ennahda party in the October 2011 elections the protest movement was essentially borne by the secular segments of Tunisia's society (Lynch 2012; Noueihed and Warren 2012).

\section{CONCLUSION: THE INTERNET AND SOCIAL MEDIA AS A RESOURCE}

This article has shown how the use of the Internet and social media in Tunisia contributed to the mobilization of anti-government protests with a particular focus on those who were digitally active. The paper has made clear that Tunisia's early commitment to ICT infrastructure development (somewhat unwittingly) created an essential resource for the mobilization of nation-wide anti-regime protests. Increased frustration at the absence of socio-economic opportunity coupled with increasing exercise of government restrictions on internet use for political purposes provided the conditions from which significant cyberactivism was made possible. Digital elites traded on past examples of cyber activism, aggregated stories of government abuse and used technology to bypass state authorities to broadcast images and narratives about the Ben Ali regime that provided the information basis upon which movement activists were able to build. Internet use and social media 
helped overcome censorship barriers to information and provided a significant resource for individuals to calculate their 'risk threshold' and respond to the growing sense of crisis. The internet and social media contributed to transcend geographical and socio-economic disparities and provided the basis to construct a national collective identity supportive of protest action against an increasingly unpopular regime. In this way, the internet served as the foundation for the articulation and aggregation of grievance, and acted as a significant resource that helped overcome problems of collective action and foment a successful protest movement that resulted in regime change. Our narrative analysis based on the background interviews and secondary sources showed how digital elite was able to use the existing infrastructure to bypass government controls and build support for a broader opposition movement. Our quantitative analysis showed consistent and overlapping opposition to the regime and a continuum of internet use that were translated into a greater propensity for engaging in political protest activity. In this way, we think it is plausible to conclude that the Internet makes a significant contribution to protest mobilization and in particular under authoritarian rule offers a route for overcoming collective action problems in ways that can galvanize opposition to unsavory regimes. 
Endnotes

${ }^{1}$ Censor 404

${ }^{2}$ Tunisian slang expression, roughly equivalent to "bollocks" or "don't break my balls".

${ }^{3}$ The core

${ }^{4}$ http://globalvoicesonline.org/

${ }^{5}$ http://mepi.state.gov/

${ }^{6}$ Translation was essential given that many Tunisian users post in Derya, the Tunisian dialect which is barely comprehensive to non-Tunisian Arabic speakers.

${ }^{7}$ Yassine Ayari, blogger and cyber-activist, interview conducted in Tunis, $18^{\text {th }}$ October 2011

${ }^{8}$ http://www.aljazeera.com/news/africa/2010/12/2010122063745828931.html

${ }^{9}$ Ben Ali step down!

${ }^{10}$ http://www.youtube.com/watch?v=vPr8ENP-zeE,

${ }^{11}$ Haythem El Mekki, blogger and political commentator on TV channel El Watanayah, interview conducted in Tunis, 17 October 2011.

${ }^{12}$ Sara Ben Hamadi, Blogger for Arte TV, interview conducted in Tunis, 19 October 2011.

${ }^{13}$ Nadia Zouari, Interview conducted in Tunis, 17 October 2011.

${ }^{14}$ The total is greater than $100 \%$ as respondents have multiple accounts.

${ }^{15}$ Respondents were offered three frequency options ranging from never (1) to frequently (4)

${ }^{16}$ Ordered probit calculates the degree to which independent variables raise the probability of a respondent moving into higher levels on an ordinal scale. 


\section{References}

Aday, Sean, Henry Farrell, Marc Lynch, John Sides, John Kelly, and Ethan Zuckerman. 2010. Blogs and Bullets: New Media in Contentious Politics. Washington DC: United States Institute of Peace. 65.

Berger, Jonah, and Katherine L. Milkman. 2010. "Social Transmission, Emotion, and the Virality of Online Content." Wharton School of the University of Pennsylvania.

Bimber, Bruce A., and Laura Copeland. 2011. "Digital Media and Political Participation Over Time in the US: Contingency and Ubiquity." Presented at the Annual Meeting of the European Consortium for Political Research, Reykjavik, Iceland.

Boix, Charles, and Milan Svolik. 2008. "The Foundations of Limited Authoritarian Government: Institutions and Power-sharing in Dictatorships." Presented at the Conference on Dictatorships: Their Governance and Social Consequences, Princeton.

Boulianne, Shelley. 2009. Does Internet use affect engagement? A meta-analysis of research. Political Communication 26 (2): 193-211.

Brady, Henry, Sidney Verba, and Kay Lehman Schlozman. 1995. Beyond SES: A resource model of political participation. American Political Science Review 89 (2): 271-294

Carroll, William K., and R.S. Ratner. 1996. Master Framing and Cross-Movement Networking in Contemporary

Social Movements. The Sociological Quarterly 37 (4): 601-625.

Chen, Xi. 2009. The Power of "Troubleemaking": Protest Tactics and Their Efficacy in China. Comparative Politics 41 (4): 451-471.

Chomiak, Laryssa. 2011. The Making of a Revolution in Tunisia. Middle East Law and Governance 3: 68-83.

Chowdhury, Mridul. 2008. "The Role of the Internet in Burma's Saffron Revolution." In Internet \& Democracy Case Study Series, ed. Berkman Center for Internet \& Society. Cambridge: Harvard University.

Colomer, Josep 2011. es, Cairo Can Happen in Havanna. Cuban Affairs 6 (1).

Colomer, Josep, and M. Pascual. 1994. The Polish Games of Transition. Communist and PostCommunist Studies 27 (3): 275-294.

Dalton, Russell J., and Alix van Sickle. 2005. "The Resource, Structural, and Cultural Bases of Protest." In Center for the Study of Democracy (CSD) Working Papers: University of California.

Dubai School of Government. 2011. Facebook Usage: Factors and Analysis.

Eckstein, H. . 1975. "Case-study and Theory in Political Science." In Handbook of Political Science, eds. F.I. Greenstein and Polsby N.S. MA: Addison-Wesley. 79-137.

ELTANTAWY, Nahed, and Julie B. Wiest. 2011. Social Media in the Egyptian Revolution: Reconsidering Resource Mobilization Theory. International Journal of Communication 5: 1207-1224.

Esseghaier, Mariam. 2013. "Tweeting Out a Tyrant:" Social Media and the Tunisian Revolution Journal of Mobile Media 7 (1).

Fjelde, Hanne. 2010. Generals, Dictators, and Kings: Authoritarian Regimes and Civil Conflict, 19732004 Conflict Management and Peace Science 27 (3): 195-218.

Foweraker, J. . 1989. of Making Democracy in Spain: Grassroots Struggle in the South, 1955-1975. Cambridge: Cambridge University Press.

-- - 1995. Theorizing Social Movements. London: Pluto.

Foweraker, J., and A. Craig. 1990. Popular Movements and Political Change in Mexico. Boulder, CO: Lynne Reiner.

Foweraker, J., and T. Landman. 1997. Citizenship Rights and Social Movements: A Comparative and Statistical Analysis. Oxford: Oxford University Press.

Friedman, Debra, and Doug McAdam. 1992. "Collective Identity and Activism. Networks, Choices and the Life of a Social Movement." In Frontiers in Social Movement Theory, eds. Aldo D. Morris and Carol McClurg Mueller: Yale University Press. 156-172. 
Geddes, Barbara. 2003. Paradigms and Sand Castles: Theory Building and Research Design in Comparative Politics. Ann Arbor: University of Michigan Press.

- - . 2006. "Why Parties and Elections in Authoritarian Regimes?" Presented at the Annual Meeting of the American Political Science Association, Washington DC.

Gerber, Alan S., Gregory A. Huber, David Doherty, Conor M. Dowling, Ha Shang, GREGORY A. HUBER ALAN S. GERBER, DAVID DOHERTY, and CONOR M. DOWLING Yale University, and SHANG E. HA. 2010. Personality and Political Attitudes: Relationships across Issue Domains and Political Contexts. American Political Science Review 104 (1): 111-133.

Geser, Hans. 2001. "On the functions and Consequences of the Internet for social movements and voluntary associations," Online Publications: Sociology in Switzerland.

Gibson, Rachel K. , Philip E. N. Howard, and Stephen Ward. 2000. "Social Capital, Internet Connectedness Political Participation: A Four-Country Study " Presented at the International Political Science Association Annual Conference, Quebec.

Goldstein, Joshua. 2007. "The Role of Digital Networked Technologies in the Ukranian Orange Revolution." In Internet \& Democracy Case Study Series, ed. Berkman Center for Internet \& Society. Cambridge: Harvard University.

Goldstein, Joshua, and Juliana Rotich. 2008. "Digitally Networked Technology in Kenya's 2007-2008 Post-Election Crisis." In Internet \& Democracy Case Study Series, ed. Berkman Centre for Internet \& Society. Cambridge: Harvard University.

Granovetter, Mark. 1978. Threshold Models of Collective Behavior. American Journal of Sociology 83: 1420-1443.

Gränzer, S. . 1999. "Changing Discourse: Transnational Advocacy Networks in Tunisia and Morocco." In The Power of Human Rights: International Norms and Domestic Change, eds. T. Risse, S.C. Ropp and K. Sikkink. Cambridge: Cambridge University Press. 109-133.

Guriev, Segei, and Konstantin Sonin. 2009. Dictators and Oligarchs: A Dynamic Theory of Contested Property Rights. Journal of Public Economics 39 (1): 1-13.

Hawkins, D. 2002. International Human Rights and Authoritarian Rule in Chile. Lincoln: University of Nebraska Press.

Hendrix, Cullen, Stephan Haggard, and Beatriz Magaloni. 2009. "Grievance and Opportunity: Food Prices, Political Regime, and Protest." Presented at the Annual Convention of the International Studies Association New York.

Howard, Philip E. N. 2011. The Digital Origins of Dictatorship and Democracy. Information Technology and Political Islam. Oxford, New York: Oxford University Press.

International Crisis Group. 2011. Popular Protest in North Africa and the Middle East (IV): Tunisia's Way. N¹06.

John, Peter, Scott Hale, and Helen Margetts. 2011. "Leadership without Leaders? Starters and Followers in On-Line Collective Action." Presented at the European Council of Political Research, Reykjavik.

Kalathil, Shanthi, and Taylor C. Boas. 2001. China, Cuba, and the Counterrevolution. First Monday 6 $(8-6)$.

Kaye, Barbara K., and Thomas J. Johnson. 1999. Taming the cyber frontier: Techniques for improving online surveys. Social Science Computer Review 17 (3): 323-337.

Kelly, John, and Bruce Etling. 2008. "Mapping Iran's Online Public: Politics and Culture in the Persian Blogosphere," (Cambridge, MA: Berkman Center Research

Publication, Harvard University, April 2008);." In Internet and Democracy Case Study Series, ed. Berkman Center for Internet and Society. Cambridge: Harvard University.

Kricheli, Ruth, Yair Livne, and Beatriz Magaloni. 2011. "Taking to the Streets. Theory and Evidence on Protests under Authoritarianism." Presented at the APSA Annual Meeting.

Krueger, Brian S. 2006. A Comparison of Conventional and Internet Political Mobilization American Politics Research 34: 759-776.

Kuebler, Johanne. 2011. Overcoming the Digital Divide: The Internet and Political Mobilization in Egypt and Tunisia CyberOrient 5 (1). 
Landman, T. 2008 Issues and Methods in Comparative Politics. London and Oxford: Routledge.

Lim, Merylina. 2013. 'White lies' , hybrid networks, and collective/connective action in the $2010-11$ Tunisian uprising. Journalism 0 (0): 1-21.

Lowrance, Sherry. 2006. Identity, Grievances, and Political Action:Recent Evidence from the Palestinian Community in Israel. International Political Science Review 27 (2): 167-190.

Lynch, Daniel C. . 1999. After the propaganda state: Media, politics and 'thought work' in reformed China. Stanford: Stanford University Press.

Lynch, Marc. 2012. The Arab Uprising. The Unfinished Revolutions of the New Middle East. New York: Public Affairs.

Magaloni, Beatriz. 2008. Credible Power-Sharing and the Longevity of Authoritarian Rule. Comparative Political Studies 41 (4): 715-741.

McAdam, Doug, Sidney Tarrow, and C. Tilly. 2001. Dynamics of Contention. Cambridge: Cambridge University Press.

McAdam, Doug, Sidney Tarrow, and Charles Tilly, eds. 2001. Dynamics of Contention. Cambridge: Cambridge University Press.

Mondak, J. J 2010. Personality and the Foundations of Political Behavior Cambridge: Cambridge University Press.

Norman, Andrew T., and Cristel A. Russell. 2006. The Pass-Along Effect: Investigating Word-of-Mouth Effects on Online Survey Procedures. Journal of Computer-Mediated Communication 11 (4): 1085-1103.

Norris, Pippa. 2001. Digital Divide. Civic Engagement, Information Poverty, and the Internet Worldwide. Cambridge: Cambridge University Press.

Noueihed, Lin, and Alex Warren. 2012. The Battle for the Arab Spring: Revolution, Counter Revolution and the Making of a New Era. New Haven.

OpenNet Inititative. 2009. Internet Filtering in Tunisia.

Pierce, Roy, and Philip E. Converse. 1990. Attitudinal Sources of Protest Behavior in France: Differences Between Before and After Measurement. Public Opinion Quarterly 54 (3): 295316.

Przeworski, Adam. 1991. Democracy and the Market. Cambridge: Cambridge University Press.

Putnam, Robert D. . 2000. Bowling Alone: The Collapse and Revival of American Community. New York: Simon \& Schuster.

Putnam, Robert D., and Lewis M. Feldstein. 2003. Better Together: Restoring the American Community. New York: Simon \& Schuster

Rahimi, Babak. 2003. Cyberdissent: The Internet in Revolutionary Iran. Middle East Review of International Affairs 7 (3): 101-115.

Reporters Without Borders. 2004. "Internet Under Surveillance 2004 - Tunisia." http://www.unhcr.org/refworld/docid/46e691963a.html

Risse, T. , S.C. Ropp, and K. Sikkink, eds. 1999. The Power of Human Rights: International Norms and Domestic Change,. Cambridge: Cambridge University Press.

Saidani, Mounir. 2012 Revolution and Counterrevolution in Tunisia: The Forty Days That Shook the Country. boundary 2 boundary 2 (39): 43-54.

Salganik, M. J., and D. D. Heckathorn. 2004. Sampling and Estimation in Hidden Populations Using Respondent-Driven Sampling. Sociological Methodology 34 (1): 193-239.

Schraeder, Peter J., and Hamadi Redissi. 2011. Ben Ali's Fall. Journal of Democracy 22 (3): 5-18.

Tarrow, Sidney. 1994. Power in Movement: Social Movements, Collective Action, and Politics. Cambridge: Cambridge University Press.

Tezcür, Günes Murat. 2012. Democracy promotion, authoritarian resiliency, and political unrest in Iran. Democratization 19 (1): 120-140.

Tilly, Charles 2004. Social Movements, 1768-2004. Boulder: Paradigm Publishers.

Tullock, Gordon. . 2005. The Social Dilemma of Autocracy, Revolution, Coup d'Etat and War.: Liberty Fund Inc.

van Laer, Jeroen. 2011. "Why people protest." PhD Universiteit Antwerpen. 
van Laer, Jeroen, and Peter van Aelst. 2009. "Cyber-protest and civil society: the Internet and action repertoires in social movements." In Handbook of Internet Crime, eds. Yvonne Jewkes and Majid Yar: Willan. 230-254.

Weitz, Richard. 2010. Iran's Grassroot Voices and the Blogosphere. Eurasia Review.

Wellman, Barry, Anabel Quan-Haase, Jeffrey Boase, and Wenhong Chen. 2003. The Social Affordances of the Internet for Networked Individualism. Journal of Computer-Mediated Communication 8 (3).

Xenos, M., and P. Moy. 2007. Direct and Differential Effects of the Internet on Political and Civic Engagement. Journal of Communication 57: 704-718.

URL: http://mc.manuscriptcentral.com/fdem Email: Aurel.Croissant@urz.uni-heidelberg.de;Jeffhaynes106868@aol.com 


\begin{tabular}{|l|c|c|}
\hline Country & Pageviews & Users \\
\hline Canada & $85.9 \%$ & $43.6 \%$ \\
\hline France & $2.8 \%$ & $11.3 \%$ \\
\hline Morocco & $2.0 \%$ & $7.7 \%$ \\
\hline Other & $9.4 \%$ & $37.5 \%$ \\
\hline
\end{tabular}

Table 1: Country Traffic for Nawaat.org prior to January 2011 
Table 2: Descriptive summaries for the key variables from the on-line survey

\begin{tabular}{|c|c|c|c|c|c|}
\hline & Variable name & $\begin{array}{l}\text { Minimum } \\
\text { value }\end{array}$ & $\begin{array}{l}\text { Maximum } \\
\text { value }\end{array}$ & $\begin{array}{l}\text { Standard } \\
\text { deviation }\end{array}$ & $\begin{array}{l}\text { No of valid } \\
\text { observations }\end{array}$ \\
\hline \multirow[t]{5}{*}{ Offline protest activities } & $\begin{array}{l}\text { Polact } \\
\text { (composite measure) }\end{array}$ & 3 & 16 & 2.933 & 323 \\
\hline & Disspolfrnds & 1 & 4 & 0.723 & 322 \\
\hline & Worepolbadge & 1 & 4 & 1.094 & 318 \\
\hline & Distpollit & 1 & 4 & 1.153 & 318 \\
\hline & Partdem & 1 & 4 & 1.006 & 320 \\
\hline \multirow[t]{8}{*}{$\begin{array}{l}\text { Internet used for protest } \\
\text { activities }\end{array}$} & $\begin{array}{l}\text { Internetusepro } \\
\text { (composite measure) }\end{array}$ & 3 & 28 & 5.343 & 350 \\
\hline & dispolknown2 & 1 & 4 & 0.766 & 345 \\
\hline & dispolstrangers2 & 1 & 4 & 1.128 & 341 \\
\hline & infosearch2 & 1 & 4 & 0.768 & 341 \\
\hline & iocalinfosearch2 & 1 & 4 & 0.837 & 344 \\
\hline & infosharefriends2 & 1 & 4 & 0.938 & 339 \\
\hline & infosharestrngrstunis2 & 1 & 4 & 1.188 & 336 \\
\hline & infoshareoutside2 & 1 & 4 & 1.169 & 338 \\
\hline \multirow[t]{5}{*}{ Opposition to Ben Ali regime } & $\begin{array}{l}\text { Govsup } \\
\text { (composite measure) }\end{array}$ & 1 & 16 & 2.274 & 436 \\
\hline & Govmanecon & 1 & 4 & 0.819 & 435 \\
\hline & Govmakjobs & 1 & 4 & 0.660 & 430 \\
\hline & Govredist & 1 & 4 & 0.559 & 428 \\
\hline & Govanticorr & 1 & 4 & 0.443 & 429 \\
\hline & & . & & & \\
\hline \multirow[t]{5}{*}{$\begin{array}{l}\text { Respect for rights and } \\
\text { freedoms }\end{array}$} & $\begin{array}{l}\text { Rightsscale } \\
\text { (composite measure) }\end{array}$ & 3 & 16 & 2.154 & 435 \\
\hline & Govprotspch & 1 & 4 & 0.500 & 433 \\
\hline & Govpropress & 1 & 4 & 0.445 & 423 \\
\hline & Polrespct & 1 & 4 & 0.830 & 429 \\
\hline & Polresrights & 1 & 4 & 0.661 & 435 \\
\hline \multirow[t]{4}{*}{$\begin{array}{l}\text { Weak sense of political } \\
\text { efficacy before revolution }\end{array}$} & $\begin{array}{l}\text { Polefficprerev } \\
\text { (composite measure) }\end{array}$ & 4 & 12 & 1.874 & 404 \\
\hline & Prerevpoleff & 1 & 4 & 0.770 & 403 \\
\hline & Prerevwellinf & 1 & 4 & 0.973 & 399 \\
\hline & Prerevdiscuss & 1 & 4 & 0.690 & 395 \\
\hline \multirow[t]{6}{*}{$\begin{array}{l}\text { Support for conservative } \\
\text { religious views }\end{array}$} & $\begin{array}{l}\text { Religviews } \\
\text { (composite measure) }\end{array}$ & 2 & 18 & 3.957 & 308 \\
\hline & relinoff2 & 1 & 4 & 1.119 & 306 \\
\hline & favsharia2 & 1 & 4 & 1.194 & 305 \\
\hline & Relnoinflnce & 1 & 4 & 0.987 & 308 \\
\hline & Govtprotrelfreed & 1 & 4 & 0.591 & 304 \\
\hline & Relsep & 1 & 4 & 1.191 & 306 \\
\hline Level of education & Educ & 2 & 5 & 0.676 & 309 \\
\hline Present occupational status & Currem & 1 & 6 & 1.987 & 303 \\
\hline Age & age2 & 1 & 6 & 1.426 & 299 \\
\hline Gender & Gender & 1 & 2 & 0.417 & 304 \\
\hline
\end{tabular}

Annex 2 provides further details on these variables. 
Table 3. Internet use and the propensity for non-internet political activity during the Tunisian Revolution

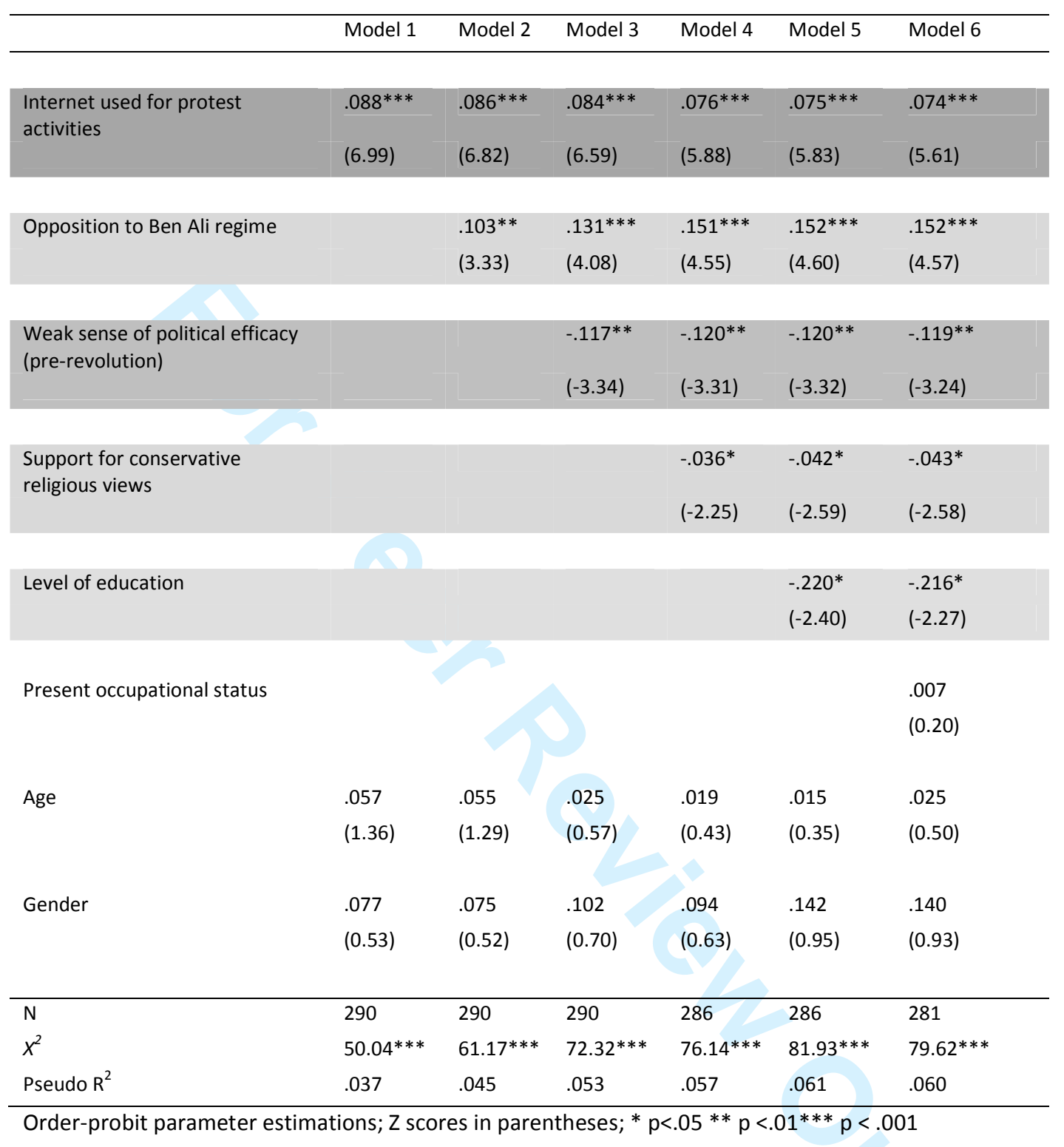

44

45

46

47

48

49

50

51

52

53

54

55

56

57

58

59

60

URL: http://mc.manuscriptcentral.com/fdem Email: Aurel.Croissant@urz.uni-heidelberg.de;Jeffhaynes106868@aol.com 


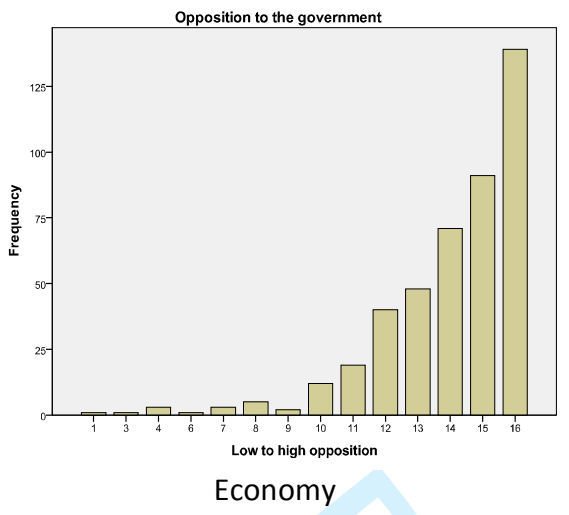

(Economy, jobs, income distribution and corruption)

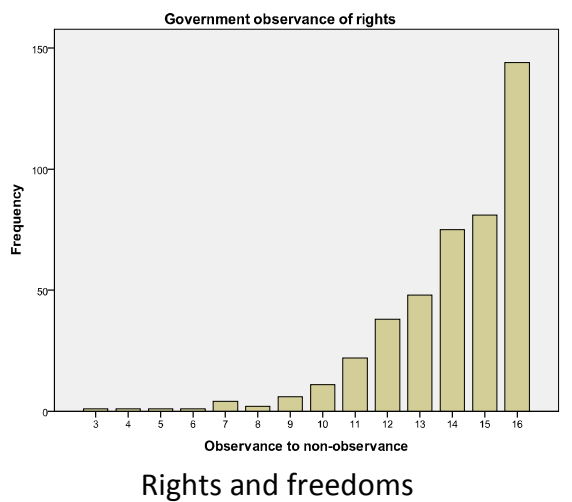

(Press, speech and general state of rights)

Figure 1. Levels of opposition to the Ben Ali Regime 


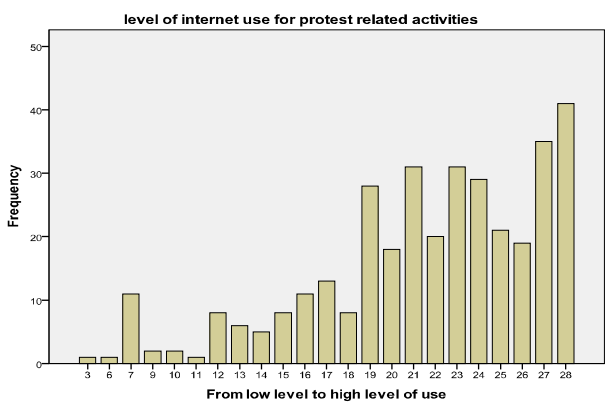

Internet use for protest-related activities (discussion, searches, sharing)

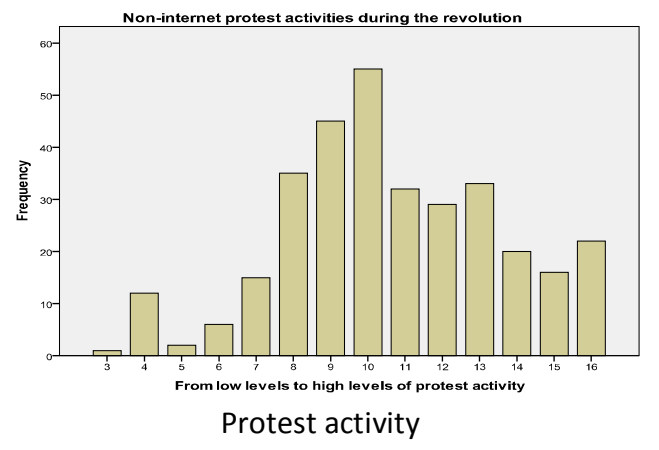

(demonstration, leafleting, displaying political messages, discussion)

Figure 2. Internet use for protest-related activities and protest activities during the revolution 


1
2
3
4
5
6
7
8
9
10
11
12
13
14
15
16
17
18
19
20
21
22
23
24
25
26
27
28
29
30
31
32
33
34
35
36
37
38
39
40
41
42
43
44
45
46
47
48
49
50
51
52
53
54
55
56
50

URL: http://mc.manuscriptcentral.com/fdem Email: Aurel.Croissant@urz.uni-heidelberg.de;Jeffhaynes106868@aol.com 


\section{Annex 1: On-line convenience sample and socio-demographics in Tunisia}

The sample that resulted from our on-line awareness and promotion is relatively old compared to the general Tunisian population with $21.9 \%$ of respondents born in the 1970 s, $38.2 \%$ in the $1980 \mathrm{~s}$, and $9.9 \%$ born in the $1990 \mathrm{~s}$. The corresponding age distribution as percentage of total population in 2010 is as follows: $15.6 \%$ born in the 1970 s, $18.4 \%$ born in the 1980 s, and $16.8 \%$ born in the 1990 s $16.8 \%$ (United States Census Bureau). Altogether, the mean age is 36 years old. With $77.6 \%$ of male respondents, the sample studied here is clearly more male-dominated than Tunisia's total population (50 \% males, World Bank 2011) and also more male than the country's Facebook population $(58.0 \%$; see www.socialbakers.com).

The sample population is also relatively highly educated with $49.8 \%$ of respondents holding a Bachelor and $37.0 \%$ a graduate degree, compared to the Tunisian population in general where the gross tertiary enrollment ratio is $28,6 \%$ (UNESCO 2010) and the gross tertiary completion ratio $6.2 \%$ (African Economic Outlook 2012). The majority of respondents in this sample are medium to heavy users of the Internet with $28.3 \%$ reporting a daily Internet use of 3-4 hours and another $43.6 \%$ reporting daily Internet use of more than 5 hours per day. To set this roughly into proportion with the Internet usage patterns of the general Tunisian population: According the the ITU household survey of 2010 , only $17.1 \%$ of individuals over the age of ten had accessed the Internet in the past 12 months. Network embeddedness among these respondents is also relatively high. 98.5\% indicated Facebook as their most important online social network, and $65.4 \%$ reported having more than 200 friends on their most important network, which is well above the worldwide average (The average number of "friends" in a Facebook network is 130). Though not generalizable on these features to the larger Tunisian population, the sample does provide valuable insights into a subset of 
1

2

3

4

5

6

7

8

9

10

11

12

13

14

15

16

17

18

19

20

21

22

23

24

25

26

27

28

29

30

31

32

33

34

35

36

37

38

39

40

41

42

43

44

45

46

47

48

49

50

51

52

53

54

55

56

57

58

59

60
Tunisian citizens previously shown to have been well educated, digitally literate, and socially interconnected. 


\section{Annex 2: Further details on key variables}

\section{Offline protest activities}

Below is a list of different forms of political action that people may undertake offline in their real life. For each of these activities please tell us whether between December 2010 and January 2011 you engaged or considered engaging in one of these activities (question $18 \mathrm{a}-\mathrm{d}$; variables 76 - 79).

Discussing the political situation face to face with relatives, friends, colleagues, or neighbors

Wearing a button, sign, or sticker with a political message

Distributing political information material (leaflets, brochures etc)

Participating in demonstrations

These were responses were summed to create a scale of offline protest activities (variable 132 polact)

Internet used for protest activities

Thinking about different activities that people can perform on the Internet in relation to politics, please indicate in which of them you engaged and how often during the revolution (question 15 a - g; variables 56 62)

Discuss online/ Chat about the political situation and its causes with unknown people

Search for information about the protest movement and related events in other parts of the country

Search for information about the protest movement and related events in my own city/town/municipality

Share/distribute information about the protest movement and related events with friends/relatives/neighbors/colleagues

Share/distribute information with unknown people living inside Tunisia

Share/distribute information with people living outside Tunisia

The original question ordered responses 1 = once 2 = Several times $3=$ Often $4=$ Never

These were recoded so that the response order was $1=$ Never 2 = Once 3 = Several times 4 = Often (variables 125-131) and then summed (variable 136 internetusepro)

Opposition to Ben Ali regime

\section{Respondents views towards Ben Ali Regime's policies (govsup)}

First of all, how well or badly would you say the government of Ben Ali was at handling the following matters? (Question 1 a -d; variables 3-6)

How effectively did government narrow gap between rich and poor (govredist)

How effectively did government create jobs (govmakjobs)

How effectively did government manage economy (govmanecon)

How effectively did government combat corruption (govanticorr)

Responses were coded $1=$ very good $2=\operatorname{good} 3=$ bad $4=$ very bad ie from strong to weak support and summed (variable 133 govsup)

Rights and Freedoms (rightsscale) 
Under the government of Ben Ali, to what extent do you think were the following freedoms guaranteed in Tunisia? (question 3 a - b)

Freedom of speech

Freedom of press

How much would you agree to the following statements: (question $4 a-b$ )

When having contact with the police I was always treated with respect

The police respected people's rights

\section{Weak sense of political efficacy before revolution}

how much would you agree to the following statements? (Question 6 a - c; variables 14-16)

Prior to the revolution, people like me could influence the way in which political decisions were taken in Tunisia

Prior to the revolution I felt well informed about the political situation in Tunisia and I felt sufficiently informed to discuss politics with other people.

I felt confident to freely discuss the political situation in Tunisia with other people.

Responses were coded 1 = agree strongly 2 = agree 3 = disagree 4 = disagree strongly ie from strong to weak sense of political efficacy and summed (variable 141 polefficprerev)

\section{Support for conservative religious views}

People think differently about how politics and religion should relate. For each of the following statements please tell us how much you agree or disagree (Question26 a to e; variables 26 a - e)

a. Religious leaders should not influence government (relnoinflnce)

b. It would be better for Tunisia if more people with strong religious beliefs held public office (relinoff)

c. The government should protect religious freedom (govtptotrelfreed)

d. Religious practice is a private matter and should be separated from socioeconomic life (relsep)

e. The government should make laws according to Islamic law / the laws of the shari'a (favsharia) Responses went from $1=$ agree strongly 2 = agree 3 = disagree 4 = disagree strongly

The responses to b. and e. were recoded ( $b$ - relinoff2 variable 137; e - favsharia2 variable 138) ) so that all responses ran from liberal to conservative; the responses were then summed religviews variable 139)

Level of education

What is your highest completed educational level

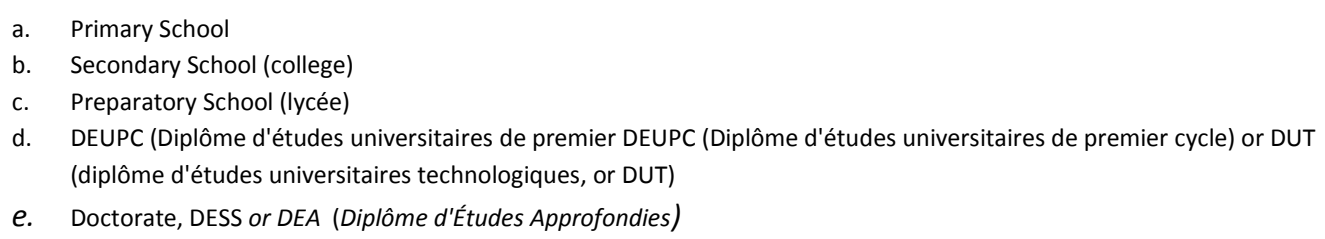


Present occupational status (curremp)

Age (age2)

Gender (gender)

(

10

11

12

14

15

16

17

18

19

20

21

22

23

24

25

26

27

28

29

30

31

32

33

34

35

36

37

38

39

40

41

42

43

44

45

46

47

48

49

50

51

52

53

54

55

56

57

58

59

60

URL: http://mc.manuscriptcentral.com/fdem Email: Aurel.Croissant@urz.uni-heidelberg.de;Jeffhaynes106868@aol.com 